AIDS, Publish Ahead of Print

DOI: 10.1097/QAD.0000000000002263

\title{
GCH1 Haplotypes and Cardiovascular Risk in HIV
}

James E. SLAVEN ${ }^{\mathrm{a}}$, David W. HAAS ${ }^{\mathrm{b}}$, Ziyue LIU ${ }^{\mathrm{a}}$, James H. STEIN ${ }^{\mathrm{c}}$, Todd T. BROWN ${ }^{\mathrm{d}}$, and Samir K. GUPTA ${ }^{\mathrm{e}}$

${ }^{a}$ Department of Biostatistics, Indiana University School of Medicine, Indianapolis, Indiana, USA

${ }^{b}$ Department of Medicine, Vanderbilt University, Nashville, Tennessee, USA

${ }^{\mathrm{c}}$ Department of Medicine, University of Wisconsin, Madison, Wisconsin, USA

${ }^{\mathrm{d}}$ Department of Medicine, Johns Hopkins University, Baltimore, Maryland, USA

${ }^{\mathrm{e}}$ Department of Medicine, Indiana University School of Medicine, Indianapolis, Indiana,

USA

Corresponding Author and Reprint Requests: Dr. Samir K. Gupta, Division of Infectious

Diseases, Indiana University School of Medicine; Emerson Hall, Suite 421, 545 Barnhill

Drive, Indianapolis, IN 46202, USA; phone: 317-274-7926; fax: 317-274-1587; email:

sgupta1@iu.edu

Conflicts of Interest and Sources of Funding. All authors, none declared. This project was supported by the Indiana Clinical and Translational Sciences Institute, funded in part by Award Number UL1TR002529 from the National Institutes of Health, National Center for Advancing Translational Sciences, Clinical and Translational Sciences Award and by the National Institute of Allergy and Infectious Diseases of the National Institutes of Health under Award Number UM1AI068634, UM1AI068636 and UM1AI106701. The content is solely the responsibility of the authors and does not necessarily represent the official views of the National Institutes of Health. 


\section{Summary}

Heightened systemic inflammation contributes to cardiovascular (CVD) events in people living with HIV (PLWH), though not all PLWH develop CVD, thus suggesting a genetic modifying role. We examined GCH1 polymorphisms, which have been associated with reduced endothelial function in European populations with CVD and increased inflammation, in a racially diverse cohort of U.S. PLWH initiating antiretroviral therapy (ART). GCH1 polymorphisms differed by race and were not associated flow-mediated dilation or carotid intima media thickness before or after 48 weeks of ART.

Keywords: HIV-1; endothelial function; GCH1; nitric oxide; cardiovascular disease 


\section{Introduction}

PLWH have an increased risk of CVD[1]. Elevated markers of generalized inflammation [interleukin-6 (IL-6), high sensitivity C-reactive protein (hsCRP)] predict HIV-CVD events [2]. However, not all patients with HIV develop CVD despite increased systemic inflammation, which suggests the possibility of unknown modulators between the two. Recent data from general population studies have shown that tetrahydrobiopterin (BH4) influences atherosclerosis [3]. Endothelial nitric oxide synthase (eNOS) requires $\mathrm{BH} 4$ as an enzymatic cofactor. Without $\mathrm{BH} 4$, superoxide radicals are generated instead of nitric oxide. Vascular bioavailability of BH4 is dependent on GTP-cyclohydrolase (GTPCH), which is the key rate-limiting enzyme in the generation of $\mathrm{BH} 4$. GCH1 is the gene encoding GTPCH and is upregulated in endothelial cells when stimulated by IL-6, hsCRP, and lipopolysaccharide. Thus, vascular inflammation induces expression of $\mathrm{GCH} 1$, which in turn prompts greater production of $\mathrm{BH} 4$ to maximize eNOS function and maintain endothelial function. A specific GCH1 haplotype [rs8007267G >A, rs3783641A $>$ T, rs10483639C $>\mathrm{G}$, or 'ATG'] is associated with reductions in GTPCH, nitric oxide, and endothelial function in the setting of acute inflammation, but only to date in very specific, ethnically homogenous European populations with known CVD [3]. Heterozygotes for this haplotype are thought to have modestly lower BH4 levels whereas homozygotes have even lower BH4 availability [3-5]. Therefore, we performed the current study to determine how the GCH1 haplotype relates to CVD risk in a diverse population of patients with chronically elevated systemic inflammation, as is found in U.S. PLWH.

\section{Methods}

To address our study objective, we combined data from two AIDS Clinical Trials Group studies (A5260s and A5152s) in which genome-wide association studies were performed and 
for which the participants had undergone measurements of flow-mediated dilation (FMD) of the brachial artery, a measure of endothelial function, and carotid intima media thickness (CIMT), a measure of cumulative arterial injury. We determined the frequencies for the GCH1 ATG haplotype and also determined the frequencies for the rs $841 \mathrm{C}>\mathrm{T}$ polymorphism, which has also been associated with reduced GCH1 expression and endothelial function in other populations $[4,5]$. Data were analyzed at study entry and at follow-up times of 24 and 48 weeks (CIMT was done only measured at week 48).

Haplotypes were determined using the haplo.stat package in $\mathrm{R}$, which utilizes the Expectation-Maximization (EM) algorithm to determine haplotypes when linkage phase is ambiguous. Fisher's exact test was performed to test for Hardy-Weinberg equilibrium. Analysis of Covariance models were constructed to determine if there were significant differences in FMD and CIMT results by haplotype/SNP group with adjustments for HIV-1 RNA level and ACTG trial group. Comparisons were also performed to identify significant associations between FMD and CIMT with IL-6 and hsCRP. Outcomes were analyzed both as cross-sectional results at each baseline and at each follow-up time point and as change from baseline to follow-up. Adjustments for multiple testing were not performed.

\section{Results}

For the 296 participants with the genetic and imaging data available from these combined trials, the mean (SD) age was 36.8 (10.3) years, with $9.1 \%$ female, $30.5 \%$ black, $13.2 \%$ Hispanic, and 53.6\% white (Table 1). At trial entry (week 0), the mean (SD) CD4 was 344 (187) cells/ $\mu \mathrm{L}, \mathrm{HIV}-1 \log _{10}$ RNA level was 4.56 (0.70) copies/mL, FMD\% was 4.71 (2.65), and CIMT was $0.66(0.11) \mathrm{mm}$. The upper tertile cutoffs for IL-6 and hsCRP were $2.2 \mathrm{pg} / \mathrm{mL}$ and $2.1 \mathrm{mg} / \mathrm{L}$, respectively. Most of the study population did not carry the GCH1 ATG haplotype; only $18(6.1 \%)$ were hemizygous and $2(<1 \%)$ were homozygous. For rs $841 \mathrm{C}>\mathrm{T}$, 
$182(61.5 \%)$ were wildtype, $95(32.1 \%)$ were hemizygous, and $19(6.4 \%)$ were homozygous. All SNPs of interest met Hardy-Weinberg equilibrium except for rs8007267.

There were no significant associations between either the GCH1 ATG haplotype or rs841C $>$ T polymorphism with either FMD or CIMT at any time point or for changes in FMD or CIMT within the entire cohort (Table 1) or in any racial subgroup (data not shown). We also did not find significant associations between the ATG haplotype of rs841 polymorphisms and either IL-6 or hsCRP in the entire study group or in any racial subgroup (data not shown).

\section{Discussion}

Contrary to expectations, we found no associations between FMD and CIMT with a GCH1 haplotype previously found in a European population to be associated with reduced endothelial function in the setting of acute inflammation and with cardiovascular disease. In this European study of 376 white individuals [3], the GCH1 ATG was found in $30 \%$ of the study population ( $27 \%$ as hemizygous and $3 \%$ as homozygous). Moreover, $\mathrm{BH} 4$ levels and FMD were significantly reduced in those carrying this GCH1 haplotype, but only in those with higher hsCRP levels. Assuming that untreated HIV infection may be a CVD equivalent condition, we hypothesized that FMD would be more impaired and CIMT greater in those with higher levels of systemic inflammation, measured as hsCRP or IL-6. The lack of significant associations in our study may be due to the very low frequency of this GCH1 haplotype (and thus lower power to detect associations) in our diverse U.S. study cohort. Interestingly, 20 of the 21 individuals with this haplotype were black (20/90) with none in the white subgroup (0/158). In fact, based on the gene frequencies actually detected in our study sample, we would need to triple our study sample in order to have power greater than 0.80 to detect differences in FMD and CIMT at the various time points assessed. The FMD values in 
our study and in the European study were similar, thus there likely were no systematic differences in endothelial function measurements to explain the lack of association with GCH1 in the current study. It is also possible that the relationship between the GCH1 haplotype and endothelial function may be restricted to Europeans and/or those with established CVD, which was not the case in our HIV+ study population. Alternatively, there may be differences in linkage disequilibrium with other genes truly responsible for endothelial function integrity which may exist between European and U.S. populations leading to the discrepant results observed. Of note, studies in other populations have also found negative or opposite associations (and also with different allele frequencies) between this GCH1 haplotype and BH4 levels, endothelial function, and/or other CVD parameters [610]. We also examined a polymorphism in rs 841 that had also previously been associated with reduced GHC1 expression but again did not find associations with CVD risk as measured by FMD and CIMT. Thus, our data do not support a relationship between the GCH1 polymorphisms tested and FMD or CIMT in U.S. HIV+ individuals without established CVD either before or after ART initiation. We acknowledge that without direct measurement of circulating $\mathrm{BH} 4$ levels, we could not confirm the underlying gene-function relationship in this study sample.

These results reinforce the requirement to confirm genetic associations across different geographical, racial, and ethnic populations. Future studies should examine other potential genetic predispositions to greater CVD risk in this population.

\section{Acknowledgements}

JES and SKG drafted the initial manuscript; SKG obtained funding; JES and ZL conducted the statistical analyses; JES, DH, ZL, JS, TB, and SKG reviewed the manuscript and provided intellectual/scientific input. This project was supported by the Indiana Clinical and 
Translational Sciences Institute, funded in part by Award Number UL1TR002529 from the National Institutes of Health, National Center for Advancing Translational Sciences, Clinical and Translational Sciences Award and by the National Institute of Allergy and Infectious Diseases of the National Institutes of Health under Award Number UM1 AI068634, UM1 AI068636 and UM1 AI106701. The content is solely the responsibility of the authors and does not necessarily represent the official views of the National Institutes of Health.

Copyright @ 2019 Wolters Kluwer Health, Inc. Unauthorized reproduction of this article is prohibited. 


\section{References}

1. Freiberg MS, Chang $\mathrm{CH}$, Kuller $\mathrm{LH}$, et al. HIV infection and the risk of acute myocardial infarction. JAMA Internal Medicine 2013; 173:614-622.

2. Duprez DA, Neuhaus J, Kuller LH, Tracy R, Belloso W, De Wit S, et al. Inflammation, Coagulation and Cardiovascular Disease in HIV-Infected Individuals. PloS One 2012; 7:e44454.

3. Antoniades C, Cunnington C, Antonopoulos A, Neville M, Margaritis M, Demosthenous M, et al. Induction of vascular GTP-cyclohydrolase I and endogenous tetrahydrobiopterin synthesis protect against inflammation-induced endothelial dysfunction in human atherosclerosis. Circulation 2011; 124:1860-1870.

4. Wolkow PP, Kosiniak-Kamysz W, Osmenda G, Wilk G, Bujak-Gizycka B, Ignacak A, et al. GTP cyclohydrolase I gene polymorphisms are associated with endothelial dysfunction and oxidative stress in patients with type 2 diabetes mellitus. PloS One 2014; 9:e108587.

5. Zhang L, Rao F, Zhang K, Khandrika S, Das M, Vaingankar SM, et al. Discovery of common human genetic variants of GTP cyclohydrolase 1 (GCH1) governing nitric oxide, autonomic activity, and cardiovascular risk. J Clin Invest 2007; 117:2658-2671.

6. Belfer I, Youngblood V, Darbari DS, Wang Z, Diaw L, Freeman L, et al. A GCH1 haplotype confers sex-specific susceptibility to pain crises and altered endothelial function in adults with sickle cell anemia. Am J Hematol 2014; 89:187-193.

7. Mayahi L, Mason L, Bleasdale-Barr K, Donald A, Trender-Gerhard I, Sweeney MG, et al. Endothelial, sympathetic, and cardiac function in inherited (6R)-L-erythro-5,6,7,8tetrahydro-L-biopterin deficiency. Circ Cardiovasc Genet 2010; 3:513-522. 
8. Lazarev M, Lamb J, Barmada MM, Dai F, Anderson MA, Max MB, et al. Does the painprotective GTP cyclohydrolase haplotype significantly alter the pattern or severity of pain in humans with chronic pancreatitis? Mol Pain 2008; 4:58.

9. Kim H, Dionne RA. Lack of influence of GTP cyclohydrolase gene (GCH1) variations on pain sensitivity in humans. Mol Pain 2007; $3: 6$.

10. Wadley AL, Lombard Z, Cherry CL, Price P, Kamerman PR. Analysis of a previously identified "pain-protective" haplotype and individual polymorphisms in the GCH1 gene in Africans with HIV-associated sensory neuropathy: a genetic association study. $J$ Acquir Immune Defic Syndr 2012; 60:20-23. 
Table 1. Associations between GCH1 polymorphisms, IL-6, and hsCRP with FMD and CIMT.

\begin{tabular}{|c|c|c|c|c|c|c|c|c|c|c|c|c|c|c|c|c|}
\hline & & & \multicolumn{4}{|c|}{ ATG haplotype } & \multicolumn{4}{|l|}{ rs841 } & \multicolumn{3}{|c|}{ Entry IL-6 } & \multicolumn{3}{|c|}{ Entry hsCRP } \\
\hline $\begin{array}{l}\text { Charact } \\
\text { eristic }\end{array}$ & $\begin{array}{l}\text { W } \\
\text { ee } \\
\mathrm{k}\end{array}$ & $\mathrm{N}$ & $\begin{array}{l}\text { Non } \\
\mathrm{e} \\
(\mathrm{n}=2 \\
76)\end{array}$ & $\begin{array}{l}\text { Hemiz } \\
\text { ygous } \\
(n=18)\end{array}$ & $\begin{array}{l}\text { Homoz } \\
\text { ygous } \\
(n=2)\end{array}$ & $\begin{array}{l}\text { P- } \\
\text { val } \\
\text { ue }\end{array}$ & $\begin{array}{l}\mathrm{CC} \\
(\mathrm{n}=1 \\
79)\end{array}$ & $\begin{array}{l}\text { TC } \\
(n= \\
99)\end{array}$ & $\begin{array}{l}\text { TT } \\
(\mathrm{n}= \\
18)\end{array}$ & $\begin{array}{l}\text { P- } \\
\text { val } \\
\text { ue }\end{array}$ & $\begin{array}{l}\text { Low } \\
\text { er } \\
\text { tertil } \\
\text { es } \\
(n=1 \\
68)\end{array}$ & $\begin{array}{l}\text { Up } \\
\text { per } \\
\text { tert } \\
\text { le } \\
(n= \\
85)\end{array}$ & $\begin{array}{l}\text { P- } \\
\text { val } \\
\text { ue }\end{array}$ & $\begin{array}{l}\text { Low } \\
\text { er } \\
\text { tertil } \\
\text { es } \\
(n=1 \\
93)\end{array}$ & $\begin{array}{l}\text { Up } \\
\text { per } \\
\text { terti } \\
\text { le } \\
(n= \\
97)\end{array}$ & $\begin{array}{l}\text { P- } \\
\text { val } \\
\text { ue }\end{array}$ \\
\hline $\begin{array}{l}\text { Female } \\
\text { sex, } \\
\text { n }(\%)\end{array}$ & & & $\begin{array}{l}26 \\
(9.4 \\
)\end{array}$ & $1(5.6)$ & $0(0)$ & $\begin{array}{l}1.0 \\
0\end{array}$ & $\begin{array}{l}15 \\
(8.2 \\
)\end{array}$ & $\begin{array}{l}11 \\
(11 . \\
1)\end{array}$ & $\begin{array}{l}1 \\
(5.6 \\
)\end{array}$ & .70 & ${ }^{13}$ & $\begin{array}{l}9 \\
(10 \\
6)\end{array}$ & .48 & $\begin{array}{l}14 \\
(7.3\end{array}$ & $\begin{array}{l}11 \\
(11 . \\
3)\end{array}$ & .27 \\
\hline $\begin{array}{l}\text { White, } \\
\text { n (\%) }\end{array}$ & & & $\begin{array}{l}158 \\
(57 . \\
5)\end{array}$ & $0(0)$ & $0(0)$ & $\begin{array}{l}<. \\
01\end{array}$ & $\begin{array}{l}97 \\
(54 . \\
2)\end{array}$ & $\begin{array}{l}51 \\
(52 . \\
0)\end{array}$ & $\begin{array}{l}10 \\
(55 . \\
6)\end{array}$ & .07 & $\begin{array}{l}89 \\
(53 . \\
3)\end{array}$ & $\begin{array}{l}39 \\
(45 \\
9)\end{array}$ & .62 & $\begin{array}{l}109 \\
(56 . \\
5)\end{array}$ & $\begin{array}{l}46 \\
(47 . \\
9)\end{array}$ & .44 \\
\hline $\begin{array}{l}\text { Black, } \\
\text { n (\%) }\end{array}$ & & & $\begin{array}{l}71 \\
(25 . \\
8)\end{array}$ & $\begin{array}{l}17 \\
(94.4)\end{array}$ & $2(100)$ & & $\begin{array}{l}62 \\
(34 . \\
6)\end{array}$ & $\begin{array}{l}24 \\
(24 . \\
5)\end{array}$ & $\begin{array}{l}4 \\
(22 . \\
2)\end{array}$ & & $\begin{array}{l}50 \\
(29 . \\
9)\end{array}$ & $\begin{array}{l}32 \\
(37 \\
7)\end{array}$ & & $\begin{array}{l}56 \\
(29 . \\
0)\end{array}$ & $\begin{array}{l}32 \\
(33 . \\
3)\end{array}$ & \\
\hline $\begin{array}{l}\text { Hispani } \\
\mathrm{c}, \\
\mathrm{n}(\%)\end{array}$ & & & $\begin{array}{l}38 \\
(13 . \\
8)\end{array}$ & $1(5.6)$ & $0(0)$ & 7 & $\begin{array}{l}15 \\
(8.4 \\
)\end{array}$ & $\begin{array}{l}20 \\
(20 . \\
4)\end{array}$ & $\begin{array}{l}4 \\
(22 . \\
2)\end{array}$ & & $\begin{array}{l}23 \\
(13 . \\
8)\end{array}$ & $\begin{array}{l}11 \\
(12 \\
9)\end{array}$ & & $\begin{array}{l}24 \\
(12 . \\
4)\end{array}$ & $\begin{array}{l}14 \\
(14 . \\
6)\end{array}$ & \\
\hline $\begin{array}{l}\text { Other, } \mathrm{n} \\
(\%)\end{array}$ & & & $\begin{array}{l}8 \\
(2.9 \\
)\end{array}$ & $0(0)$ & $0(0)$ & & $\begin{array}{l}5 \\
(2.8 \\
)\end{array}$ & $\begin{array}{l}3 \\
(3.1 \\
)\end{array}$ & $\begin{array}{l}0 \\
(0)\end{array}$ & & $\begin{array}{l}5 \\
(3.0 \\
)\end{array}$ & $\begin{array}{l}3 \\
(3.5 \\
)\end{array}$ & & $\begin{array}{l}4 \\
(2.1 \\
)\end{array}$ & $\begin{array}{l}4 \\
(4.2 \\
)\end{array}$ & \\
\hline $\begin{array}{l}\text { FMD, } \\
\%\end{array}$ & 0 & $\begin{array}{l}2 \\
6 \\
8\end{array}$ & $\begin{array}{l}4.74 \\
(2.6 \\
8)\end{array}$ & $\begin{array}{l}4.34 \\
(2.86)\end{array}$ & $5.85()$. & .78 & $\begin{array}{l}4.71 \\
(2.9 \\
4)\end{array}$ & $\begin{array}{l}4.6 \\
5 \\
(2.2 \\
5)\end{array}$ & $\begin{array}{l}5.1 \\
6 \\
(2.2 \\
7)\end{array}$ & .77 & $\begin{array}{l}4.75 \\
(2.4 \\
5)\end{array}$ & $\begin{array}{l}5.2 \\
2 \\
(3.0 \\
9)\end{array}$ & .21 & $\begin{array}{l}4.52 \\
(2.4 \\
3)\end{array}$ & $\begin{array}{l}5.1 \\
3 \\
(3.1 \\
0)\end{array}$ & .08 \\
\hline & 24 & $\begin{array}{l}2 \\
4 \\
3\end{array}$ & $\begin{array}{l}5.05 \\
(2.7 \\
6)\end{array}$ & $\begin{array}{l}4.19 \\
(2.55)\end{array}$ & $\mathrm{n} / \mathrm{a}$ & .24 & $\begin{array}{l}5.06 \\
(2.8 \\
8)\end{array}$ & $\begin{array}{l}5.9 \\
7 \\
(2.6 \\
3)\end{array}$ & $\begin{array}{l}4.6 \\
5 \\
(2.2 \\
2)\end{array}$ & .83 & $\begin{array}{l}4.77 \\
(2.4 \\
8)\end{array}$ & $\begin{array}{l}5.4 \\
1 \\
(3.1 \\
3)\end{array}$ & .11 & $\begin{array}{l}4.84 \\
(2.3 \\
9)\end{array}$ & $\begin{array}{l}5.3 \\
6 \\
(3.3 \\
9)\end{array}$ & .17 \\
\hline
\end{tabular}




\begin{tabular}{|c|c|c|c|c|c|c|c|c|c|c|c|c|c|c|c|c|}
\hline & 48 & 7 & $\begin{array}{l}4.98 \\
(2.6 \\
6)\end{array}$ & $\begin{array}{l}3.90 \\
(1.86)\end{array}$ & $4.06()$. & .31 & $\begin{array}{l}4.96 \\
(2.6 \\
0)\end{array}$ & $\begin{array}{l}4.7 \\
7 \\
(2.6 \\
3)\end{array}$ & $\begin{array}{l}5.0 \\
5 \\
(2.9 \\
0)\end{array}$ & .87 & $\begin{array}{l}5.04 \\
(2.6 \\
2)\end{array}$ & $\begin{array}{l}4.6 \\
8 \\
(2.6 \\
3)\end{array}$ & .35 & $\begin{array}{l}5.00 \\
(2.5 \\
7)\end{array}$ & $\begin{array}{l}4.7 \\
7 \\
(2.7 \\
5)\end{array}$ & .56 \\
\hline & $\begin{array}{l}\text { W } \\
\text { ee } \\
\text { k } 0 \\
\text { to } \\
24\end{array}$ & 8 & $\begin{array}{l}0.28 \\
(2.8 \\
0)\end{array}$ & $\begin{array}{l}-0.17 \\
(2.96)\end{array}$ & $\mathrm{n} / \mathrm{a}$ & .55 & $\begin{array}{l}0.30 \\
(3.1 \\
0)\end{array}$ & $\begin{array}{l}0.2 \\
7 \\
(2.4 \\
4)\end{array}$ & $\begin{array}{l}- \\
0.2 \\
9 \\
(1.1 \\
7)\end{array}$ & .73 & $\begin{array}{l}- \\
0.05 \\
(2.4 \\
7)\end{array}$ & $\begin{array}{l}0.1 \\
2 \\
(3.0 \\
3)\end{array}$ & .67 & $\begin{array}{l}0.31 \\
(2.6 \\
2)\end{array}$ & $\begin{array}{l}0.1 \\
4 \\
(3.2 \\
4)\end{array}$ & .67 \\
\hline & $\begin{array}{l}\text { W } \\
\text { ee } \\
\mathrm{k} 0 \\
\text { to } \\
48\end{array}$ & 1 & $\begin{array}{l}0.03 \\
(2.9 \\
7)\end{array}$ & $\begin{array}{l}-0.87 \\
(2.32)\end{array}$ & $\begin{array}{l}-1.79 \\
\text { (.) }\end{array}$ & .46 & $\begin{array}{l}- \\
0.04 \\
(3.2 \\
1)\end{array}$ & $\begin{array}{l}- \\
0.0 \\
8 \\
(2.6 \\
3)\end{array}$ & $\begin{array}{l}0.0 \\
6 \\
(1.7 \\
5)\end{array}$ & .99 & $\begin{array}{l}0.25 \\
(2.8 \\
4)\end{array}$ & $\begin{array}{l}- \\
0.5 \\
8 \\
(3.0 \\
8)\end{array}$ & .06 & $\begin{array}{l}0.29 \\
(2.8 \\
4)\end{array}$ & $\begin{array}{l}- \\
0.6 \\
3 \\
(3.0 \\
4)\end{array}$ & $\begin{array}{l}.03 \\
*\end{array}$ \\
\hline $\begin{array}{l}\text { CIMT, } \\
\mathrm{mm}\end{array}$ & 0 & $\begin{array}{l}2 \\
4 \\
4\end{array}$ & $\begin{array}{l}0.66 \\
(0.1 \\
1)\end{array}$ & $\begin{array}{l}0.70 \\
(0.07)\end{array}$ & $0.53()$. & .26 & $\begin{array}{l}0.66 \\
(0.1 \\
0)\end{array}$ & $\begin{array}{l}0.6 \\
8 \\
(0.1 \\
4)\end{array}$ & $\begin{array}{l}0.6 \\
6 \\
(0.0 \\
9)\end{array}$ & .29 & $\begin{array}{l}0.66 \\
(0.1 \\
1)\end{array}$ & $\begin{array}{l}0.6 \\
8 \\
(0.1 \\
1)\end{array}$ & .08 & $\begin{array}{l}0.66 \\
(0.1 \\
1)\end{array}$ & $\begin{array}{l}0.6 \\
7 \\
(0.1 \\
0)\end{array}$ & .88 \\
\hline & 48 & 7 & $\begin{array}{l}0.68 \\
(0.1 \\
2)\end{array}$ & $\begin{array}{l}0.70 \\
(0.07)\end{array}$ & $0.55()$. & .45 & $\begin{array}{l}0.67 \\
(0.1 \\
0)\end{array}$ & $\begin{array}{l}0.7 \\
0 \\
(0.1 \\
4)\end{array}$ & $\begin{array}{l}0.6 \\
7 \\
(0.0 \\
9)\end{array}$ & .26 & $\begin{array}{l}0.67 \\
(0.1 \\
1)\end{array}$ & $\begin{array}{l}0.6 \\
9 \\
(0.1 \\
1)\end{array}$ & .11 & $\begin{array}{l}0.68 \\
(0.1 \\
1)\end{array}$ & $\begin{array}{l}0.6 \\
8 \\
(0.1 \\
1)\end{array}$ & .76 \\
\hline & $\begin{array}{l}\text { W } \\
\text { ee } \\
\mathrm{k} 0 \\
\text { to } \\
48\end{array}$ & 2 & $\begin{array}{l}0.01 \\
(0.0 \\
2)\end{array}$ & $\begin{array}{l}0.01 \\
(0.02)\end{array}$ & $0.02()$. & .67 & $\begin{array}{l}0.01 \\
(0.0 \\
2)\end{array}$ & $\begin{array}{l}0.0 \\
1 \\
(0.0 \\
2)\end{array}$ & $\begin{array}{l}0.0 \\
1 \\
(0.0 \\
2)\end{array}$ & .31 & $\begin{array}{l}0.01 \\
(0.0 \\
2)\end{array}$ & $\begin{array}{l}0.0 \\
1 \\
(0.0 \\
2)\end{array}$ & .23 & $\begin{array}{l}0.01 \\
(0.0 \\
2)\end{array}$ & $\begin{array}{l}0.0 \\
1 \\
(0.0 \\
2)\end{array}$ & .17 \\
\hline
\end{tabular}

The ATG haplotype consists of rs8007267G>A, rs3783641A>T, rs10483639C > G. IL-6, interleukin-6; hsCRP, high sensitivity C-reactive protein; FMD, flow-mediated dilation; CIMT, carotid intima media thickness.

Values are frequencies (percentages) for categorical variables and means (standard deviations). P-values are from Fisher's Exact tests and ANOVAs, respectively. 
Demographic variables are from baseline only. A “(.)" indicates there was only one observation and so no standard deviation could be calculated. Analyses were also adjusted for viral load and for trial (GWAS) group, with similar (non-attenuated) results. Analysis data sets include those with values at follow-up time periods (weeks 24 and 48) and so may be smaller than the full sample sizes at baseline. 